\title{
Parents' shares on Instagram in the early days of the COVID-19 pandemic
}

\author{
Sühendan $\operatorname{Er}^{\text {(D) }}$ \\ TED University, Early Childhood Education, Ankara, Turkey, suhendan.er@ @edu.edu.tr \\ Nergis Hazal Y1lmaztürk \\ TED University, Guidance and Psychological Counseling, Ankara, Turkey, hazal.yilmazturk@tedu.edu.tr \\ Tuba Özgül ${ }^{\mathbb{D}}$ \\ TED University, Early Childhood Education, Ankara, Turkey, tuba.ozgul@tedu.edu.tr \\ Figen Çok $^{\text {(D) }}$ \\ Başkent University, Guidance and Psychological Counseling, Ankara, Turkey, figen.cok@ baskent.edu.tr
}

ABSTRACT Many people had to stay at home with their families during the pandemic because of social distancing guidelines and lockdowns. This study aims to explore the content of 'sharenting' of parents during the early COVID-19 pandemic and quarantine periods in Turkey. In total, 401 posts were collected from public Instagram accounts of parents who shared their own children's photos or videos between 18th30th April 2020, via the most commonly used hashtags of \#korona (\#corona) and \#evdekal (\#stayhome). Descriptive content analysis was conducted within identified categories. Results revealed that the popular hashtag \#stayathome is particularly important for its optimistic representation of the lockdown process in society. Content analysis results show that with the inclusion of social media shares, family members spent more time together, which can be seen as one of the positive consequences of this period. In the results of continued sharenting during the early pandemic, children's faces were mainly kept visible, which might concern children's privacy. Additionally, mothers shared more during this period. Consequently, education to increase awareness of such concepts gains importance, especially for the well-being and privacy of children and any future implications.

Keywords: COVID-19, Instagram shares, Pandemic, Parents, Sharenting, Social media

\section{COVID-19 günlerinin başlarında anababaların Instagram paylaşımları}

ÖZ Pandemi sırasında birçok kişi sosyal izolasyon ve karantina nedeniyle aileleriyle birlikte evde kalmak zorunda kalmıştır. Bu çalışma Türkiye'de COVID-19'un ilk dönemlerindeki karantina günlerinde anababaların sosyal medyada çocuklarına dönük paylaşımlarının içeriğini araştırmayı amaçlamaktadır. Pandeminin ilk dönemi sayılabilecek 18-30 Nisan 2020 tarihleri arasında, Instagram paylaşımlarında popüler hashtagler olan \#korona ve \#evdekal incelenerek anababaların herkese açık Instagram paylaşımları üzerinden kendi çocuklarının fotoğraflarını/videolarını paylaştığı toplam 401 içeriğe ulaşılmıştır. Belirlenen kategoriler dâhilinde içerik analizi gerçekleştirilmiştir. Sık kullanılan \#evdekal hashtagi toplumda başkalarına karşı duyarlılık çağrışımı yapması açısından olumlu bir gelişme olarak kabul edilebilir. Betimleyici içerik analizi sonuçları, sosyal medyanın aile hayatına dahil olması ile birlikte aile üyelerinin birlikte daha çok vakit geçirmeleri vurgusu bakımından, pandemi sürecinin olumlu sonuçlarından biri olarak nitelendirileceğini göstermiştir. Pandemi sürecinde devam eden paylaşımlarda araştırma sonuçları çocukların yüzlerinin çoğunlukla erişebilir olduğunu göstermektedir. $\mathrm{Bu}$ durum, çocukların mahremiyetine ilişkin bir endişe yaratabilir. Bununla birlikte, anneler bu süreçte daha çok paylaşımda bulunmuşlardır. Sonuç olarak, özellikle çocukların psikolojik iyi oluşu ve mahremiyetlerini korumak açısından bu tür kavramların farkındalığını artırmaya yönelik eğitimler ve bunların sonraki çalışmalar açısından önem kazanmaktadır.

Anahtar Anababaların sosyal medyada çocuklarını paylaşımı, Anababalar, COVID-19, Instagram

Sözcükler: $\quad$ paylaşımları, Pandemi, Sosyal medya 


\section{INTRODUCTION}

Over the past two years, many hardships have been faced worldwide due to the COVID-19 pandemic (Sprang, \& Silman, 2013). Since the COVID-19 virus infected the first individuals in Wuhan, China, in December 2019, it spread all over the world in a short time. During the pandemic, there were many restrictions on social life, and people had to take precautions regarding hygiene and keep a distance from others in public places (Niknam et al., 2021). Most governments took action by pausing formal education (Naidui, 2021). Therefore, children were affected by physical distancing, quarantines, and closures of both private and public schools due to the spread of the Coronavirus Disease 2019 (COVID-19) across the world. Consequently, the United Nations Educational, Scientific and Cultural Organization reported that over 185 countries had decided to pause formal education, and over 1.5 billion students were affected by this decision by May 2020 (Timmons et al., 2021).

Similarly, in Turkey, the schools were closed down from March 16, 2020, and over 18.1 million preschool and primary school children had to stay at home and engage in distance learning, broadcasted by the Ministry of Education (Özer, 2020). Most private schools adopted additional online programs for their students. Social isolation started, and children and those under the age of 20 had to stay at home, so parents had to start spending more time with their children. Some children and teenagers may have felt isolated, anxious, bored, and uncertain (Imran et al., 2020). Likewise, parents experienced restrictions and similar feelings, but the digital world helped them partly cope with these feelings of living in isolation facing uncertainty.

Even when a global pandemic does not grip the world, social media is an attractive and easily accessible tool, ideal for wide-spreading public health messaging (Droin et al., 2020), and it has become an inseparable part of the parent-child relationship (Atl et al., 2019). Nowadays, parents can easily access social media platforms and see what other parents and children do together. In this modern age, social media is a platform that parents look to for inspiration on activities suitable for children and advice on parenting skills (Brosch, 2016; Lazard et al., 2019). For this purpose, they share lots of pictures or videos of their children and expect likes and reactions, which probably makes them feel better.

\section{What is Sharenting?}

'Sharenting' is a new term combining 'sharing' and 'parenting'. Parents may use social media to communicate experiences containing detailed information about their children. Even in cases where the parents are aware of potential risks, they continue sharenting because it is a way for the parents to satisfy their need for self-realisation and social approval (Davidson-Wall, 2018). On social media, parents frequently share pictures of milestones: a baby's first steps, first tooth, pictures with family and friends on holidays or at the playground; pictures considered to be cute; or pictures deemed to be funny (Kumar, $\&$ Schoenebeck, 2015). It has been observed that parents generally share pictures of happy times, such as birthdays or holidays (Brosch, 2016). Sharenting also enables parents to give or exchange advice about parenting challenges, to let friends and family stay in touch with their children, to show that they are proud parents, to collect memories, or to portray themselves as good parents (Blum-Ross, \& Livingstone, 2017; Davis et al., 2015; Maraşl1 et al., 2016). However, it can be presumed that most parents are not aware that when they are sharenting, they may be violating their children's right to privacy. Even before the birth of their child, parents publish information related to their identity, and they also put their child at risk by posting the child's photo, writing names, or disclosing the date of birth. This creates the child's 'digital footprint', which may have unpredictable consequences in years to come (Brosch, 2016). Additionally, the term 'digital kidnapping' refers to people who steal a child's identity and photo on social media and pass the child off as their own. The child may be given a new name, with a new life story and new parents. Alternatively, in some instances, parents post their children's nude or semi-nude pictures during bath time, at the seaside, or during a nappy change. They 
probably do not consider that such pictures could fall into the hands of child pornographers. Parents sometimes share funny pictures of their children, such as sitting on a potty, sleeping in a strange position, or having food on their faces. It should be kept in mind that the posts will stay on the site for years, and these pictures might embarrass the child when they're older. These pictures could be ridiculed or shared on other sites without permission, violating children's rights (Erişir, \& Erişir, 2018). Parents have long been known as a major mediator of our existence, providing a broad conceptualisation of children's development (Bronfenbrenner, 2005; Sweeney, 2009). The family is essential for forming personality, socialisation, interacting with others, and expressing love and trust. Although the family is a minor organisation of society, it can affect the structure of both the individual and the community (Demir, \& Drentea, 2016). Theorists such as Piaget, Vygotsky, Kohlberg, Erikson, Freud and Adler emphasised the importance of a qualified parent-child interaction (Ural \& Ramazan, 2007; Sweeney, 2009; Nesmith et al., 2017). The parents' well-being, mood, and personality significantly influence the child's behaviour and personality (Akee et al., 2018; Davis et al., 2015). Parents are satisfied with parental pride, which affects the development of children with adaptive developmental outcomes (Williams, 2009). Similarly, parental pride might be considered as a sign of emotionally supportive parenting. An association between pride, sharenting, and 'humblebragging' are supposed to be components of the social acceptance of parents on social media platforms (Lazard et al., 2019). Although parenting is a universal and historical issue, the COVID-19 period brought its own challenges and concerns. A new research agenda was created based on the adaptations to the new normal. Within these challenges, new parenting practices become essential to study.

\section{COVID-19 and Sharenting}

During the pandemic in Turkey, distance learning was introduced for elementary, middle, and high schools a few weeks after the pandemic declaration in March 2020. Most workplaces were closed or switched to part-time work, and many people started to work from home. A lockdown was declared for those under 20 years old and those over 65 and those with chronic diseases during the early period of the pandemic. Due to these unavoidable new living conditions, people started to use social media to cope with the difficulties of the lockdown and its restrictions. Accordingly, parents and their children were affected by these changes (Özer, 2020). This formed the motivation behind this study. The changing life conditions imposed by the lockdown resulted in an elevated use of social media, so examining parents' shares about their children on social platforms during COVID-19 seemed important. Based on careful consideration of the COVID-19 period and parents' shares in Turkey, the hashtags \#korona (\#corona) and \#evdekal (\#stayathome) were quite common and popular hashtags. Therefore, examining sharenting during the early period of the pandemic is crucial to understand the role of sharenting in parents' lives. Accordingly, this study aims to explore practices of sharenting during COVID-19 and the quarantine period in Turkey and, in turn, poses the following research questions:

1) Who shared posts during quarantine, mothers or fathers?

2) What is the developmental stage of the child depicted on social media (0-2 years old, early childhood, elementary school, middle/high school, university) during early quarantine days?

3 ) Is the child's face apparent or blurred/hidden in the posts shared by parents during early quarantine?

4) What is the direction of the post during quarantine? (Is the message positive/neutral/negative?)

5) What is the post's content (activity, criticism, daily life) during early quarantine?

6) Are there any accompanying hashtags related to COVID-19 in the posts? If so, what hashtags?

\section{METHOD}

This current study contains descriptive content analysis of the Instagram profiles of the parents. This study was designed by considering the ethical and methodological principles of internet-mediated research, which is new in the literature. According to Hewson \& Buchana's (2013) ethics guidelines for internet-mediated research, it is determined that although debates on data collection from the public 
versus private accounts have been inconsistent, public data might be used if it does not promote any harm on behalf of the social media users. Ethical considerations were granted by the human studies ethics committee from Başkent University, Faculty of Education, document number: 62310886604.02.02 on July 10, 2020. Researchers did not share any raw data, and the privacy of the data has been saved.

\section{Study Group}

The study group consisted of 401 posts. These posts include photos and videos that were shared by parents who share their children on social media. Public Instagram accounts were also a criterion for the study group regarding ethical considerations and accessibility. Parents' accounts were investigated one by one to determine whether they are the parent of the children shared. In most cases, parents had openly written descriptions along the lines of "Ali's mother" in the biography section of their Instagram account. Another way to ensure that they are the parents was by checking the comments under the post. Moreover, they used hashtags such as "my dear daughter", "my lovely son", etc. Lastly, previous parents' posts in their accounts were checked to clarify whether the shared children are their son and/or daughter. If the parental status was not clear, these posts and accounts were not included in the study. Only open and accessible accounts were reached.

\section{Data Collection}

Data were collected through public Instagram posts of parents who shared their own children's photos and videos. Stories (one-day instant posts) were not included in the study. Photos and videos are two types of Instagram shares, and they were investigated between April 18 and 30, 2020. Only posts were chosen for data analysis. To be utilised in the classification of Instagram posts, coding criteria were determined by the researchers in tune with the aim of the study.

Figure 1.

Categories to Be Analysed in Terms of Sharenting Posts

\begin{tabular}{|l|}
\hline The type of the post \\
\hline The parent who shares the post \\
\hline Developmental stage of the shared child \\
\hline Presence of child's face \\
\hline The direction of a post \\
\hline The content of the post \\
\hline
\end{tabular}

Following this, a coding sheet was formed that included the seven categories, coded daily with respect to daily data collection, and the research team reached a consensus on it. These categories, given in Figure 1, were in relation to the type of post in question (photo/video), the parent who shared the post (mother/father), the developmental stage of the shared child (0-2 years old, early childhood, elementary school, middle/high school, university), presence of the child's face (whether the parent showed their child's face or blurred/hid it), the direction of a post (whether the message given was positive/neutral/negative), the content of the post (activity, criticism, daily life and so forth), other accompanied hashtags related to COVID-19. Data were collected and numbered daily within the given period by taking screenshots of the posts from public Instagram accounts to conduct further analysis. 
A total of 401 posts between the designated dates were found and analysed. Two hundred twenty-six posts were gathered from the \#korona (\#corona) hashtag, while the rest were from the \#evdekal (\#stayhome) hashtag. These hashtags were chosen as they have been the most frequently used ones during the pandemic period, during which an emphasis was placed on the importance of self-quarantine (Lacsa, 2021). Therefore, these hashtags were set as a sampling criterion to reach parents' posts related to the pandemic. These posts are visible to the public and easily accessible for research regarding ethical considerations.

\section{Analysis}

Prior to the main data analysis, a pilot study was conducted with the data collected on 18th and 19th April 2020 to check interrater reliability (Gwet, 2014). Adapting interrater reliability based on the content analysis of the material is usually considered the main approach for this kind of research (Gwet, 2014). Accordingly, two of the authors were assigned as raters to categorise 97 selected posts for both hashtags, and the analysis was made separately. Percentage values were determined for the level of interrater reliability across each of these domains. The percentage values of agreement between the raters varied between 75\%-100\%, demonstrating a correlation (Cohen, 1960). To be more precise, interrater reliability ranged between $80 \%$ and $100 \%$ for the \#korona (\#corona) hashtag, while it was between $75 \%$ and $100 \%$ for the \#evdekal (\#stayhome) hashtag. Later, descriptive content analysis was conducted separately for each hashtag to analyse data. An inductive approach was used for the category development since given subcategories emerged from the shares (Patton, 2015).

\section{RESULTS}

Results of the study are presented in categories, including who shared the post, the developmental stage of the shared child, the presence of the child's face, the direction of the post, the content of the post, and other accompanied hashtags related to COVID-19. The frequency of posts in terms of these categories for \#korona (\#corona) and \#evdekal (\#stayhome) is presented below in Table 1.

Table 1.

Total Number of Posts Regarding Pre-Determined Categories for \#korona (\#corona) and \#evdekal (\#stayhome)

\begin{tabular}{|c|c|c|c|c|c|c|c|c|c|}
\hline \multirow[t]{3}{*}{ Hashtag } & \multicolumn{2}{|c|}{ The type of post } & \multicolumn{2}{|c|}{$\begin{array}{l}\text { The parent who } \\
\text { shares the post }\end{array}$} & \multicolumn{5}{|c|}{ Developmental stage of the shared child } \\
\hline & \multirow[b]{2}{*}{ photo } & \multirow[b]{2}{*}{ video } & \multirow[b]{2}{*}{ mother } & \multirow[b]{2}{*}{ father } & \multirow[b]{2}{*}{$\begin{array}{c}\text { Aged } \\
0-2\end{array}$} & \multirow[b]{2}{*}{ preschool } & \multicolumn{3}{|c|}{ school age } \\
\hline & & & & & & & $\begin{array}{c}\text { elementary } \\
\text { school }\end{array}$ & $\begin{array}{l}\text { high } \\
\text { school }\end{array}$ & university \\
\hline $\begin{array}{l}\text { \#korona } \\
\text { (\#corona) } \\
\text { \#evdekal }\end{array}$ & 155 & 71 & 189 & 37 & 57 & 159 & 10 & 0 & 0 \\
\hline (\#stayhome) & 112 & 63 & 137 & 38 & 36 & 104 & 34 & 1 & 0 \\
\hline \multirow[t]{2}{*}{ Hashtag } & \multicolumn{2}{|c|}{$\begin{array}{l}\text { Presence of } \\
\text { child's face }\end{array}$} & \multicolumn{3}{|c|}{ The direction of the post } & \multicolumn{3}{|c|}{ The content of the post } & Total \\
\hline & shown & hidden & positive & negative & neutral & activity & criticism & other & posts \\
\hline $\begin{array}{l}\text { \#korona } \\
\text { (\#corona) } \\
\text { \#evdekal }\end{array}$ & 207 & 19 & 167 & 38 & 21 & 51 & 25 & 150 & 226 \\
\hline (\#stayhome) & 163 & 12 & 151 & 4 & 20 & 97 & 1 & 77 & 175 \\
\hline
\end{tabular}

\section{Number of Posts, Parent Who Shared Post and the Type of Post}

The frequency of posts ranged between 9 and 23, with a mean of 17 posts per day for \#korona (\#corona) and \#evdekal (\#stayhome). Data for \#korona (\#corona) and \#evdekal (\#stayhome) has consisted of 226 posts (over a period of 13 days), which were shared by the mothers $(n=189)$ and fathers $(n=37)$ of the 
children. Their shares were investigated as photos $(n=155)$ and videos $(n=71)$. Data for \#evdekal (\#stayhome) consisted of 175 posts. Most of the posts were shared by the mother of the child $(n=137)$. The majority of the data consisted of photographs $(n=112)$, while the rest were videos $(n=63)$. The frequency of posts ranged between 5 and 35, with a mean of 13 posts per day for \#evdekal (\#stayhome). A categorical breakdown for these posts is presented in Figure 2 for both hashtags.

\section{Figure 2.}

Most Frequent Sharenting Posts Using \#korona (\#corona) and \#evdekal (\#stayhome) Regarding Pre-Determined Categories
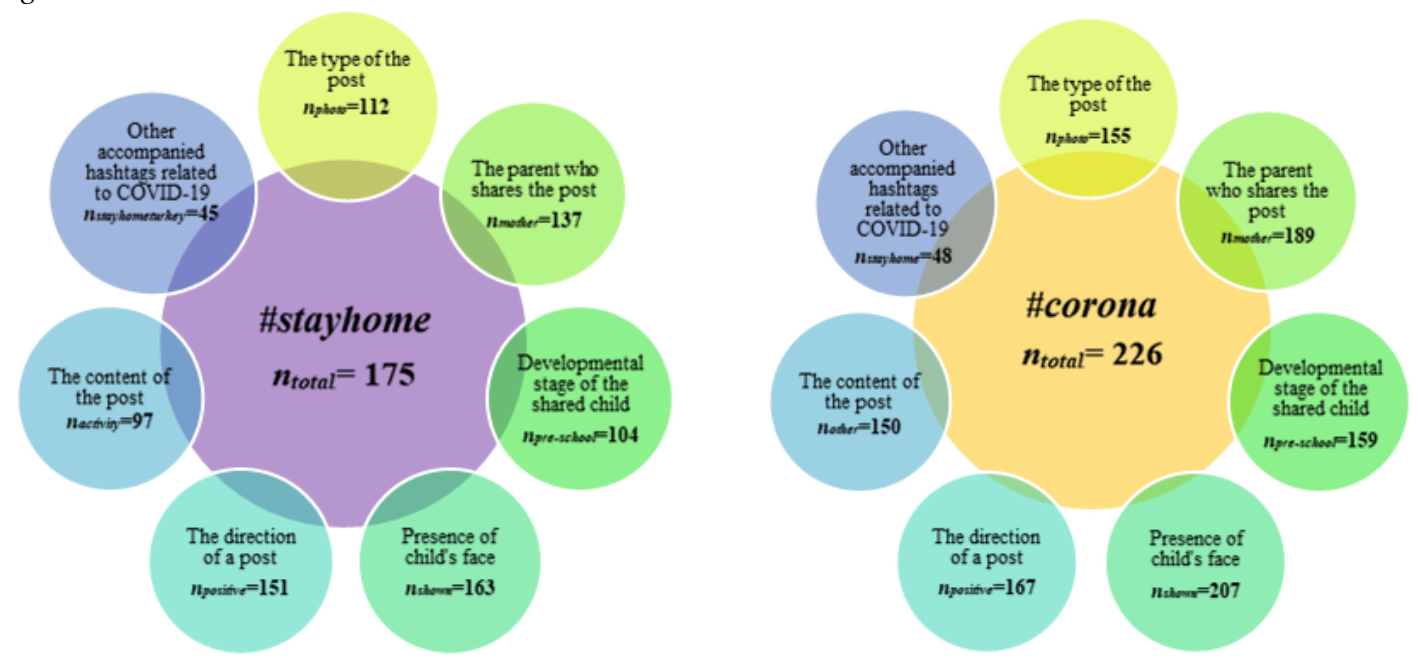

In the current study photos and videos of Instagram shares parents' about their children on were investigated between April 18 and 30, 2020 representing early COVID-19 days. Most of the posts were shared on April $23(\mathrm{n}=49)$ for both hashtags. Since April 23 is a national public holiday for children in Turkey, it is usually celebrated with ceremonies in schools, towns and cities.

\section{Developmental Stage of the Shared Children}

It was determined that the developmental stages of the children shared in the posts by their parents were mostly the preschool period, between the ages of 2-6 $(n=159)$. Shares of babies aged between $0-2$ followed, with 57 posts for \#korona (\#corona). Ten posts regarding children of primary school age were found among the parents' posts. For \#evdekal (\#stayhome), preschoolers were the most shared group $(n=104)$, followed by $0-2$ years old babies $(n=36)$ and elementary school children $(n=34)$. There was only one sharenting post of an adolescent of high school age. The results showed that young children were the primary focus of the posts made by parents.

To define the developmental stage of children, the shares were categorised as toddlers ( $0-2$ years), early childhood (2-6 years), elementary school, secondary school, and university. It was quite simple to distinguish these categories based on basic developmental periods, clearly reflected through photos and videos. As mentioned earlier, no ambiguous posts were included in terms of research criterion. The context of shares usually reflects the developmental information such as "my son started to read at 3rdgrade level" for an example of elementary school, or "my baby is teething" as an example of sharing about a toddler.

\section{Privacy of Children in Shares}

Children's faces were mostly visible ( $\mathrm{n}=207$ out of a total of 226 posts). A limited number of mothers and fathers shared their children with blurred faces $(n=17)$. However, these posts seem to have been uploaded without concerns about privacy since the children's faces were visible in the other posts of the same accounts. Only one mother who shared a post using \#korona (\#corona) did so whole hiding her 
son's face with an image of a character $(\mathrm{n}=1)$. For \#evdekal (\#stayhome), children's faces were also usually visible $(n=163)$. One mother shared a post with an emoji on her son's face $(n=1)$, while others who hid their child's face did so by taking the photograph from behind. These results reveal that the photos of children that parents share on Instagram are available to third parties, which might be questionable regarding children's confidentiality and safety.

\section{The Direction of the Shares}

The posts shared by the parents were also recorded and analysed in terms of the direction of the images posted. These were determined by the evoked emotions of the parents towards their children, such as their facial expressions, body language, or the emoticons they included in the post. The direction of the shares has generally been recorded as positive $(n=167)$. Parents shared both favourable photos and videos. Negative $(n=38)$ and neutral $(n=21)$ messages have been identified for \#korona (\#corona). In tune with the nature of social media, the direction of the content for \#evdekal (\#stayhome) was also dominated by the positive ones $(n=151)$, addressing the joy of spending time with children and/or enjoying the additional time with children due work-from-home arrangements and so on. Neutral posts $(n=21)$ and negative posts $(n=4)$ sequentially followed them. There were expressions of love towards children and the time they spent happily at home playing games or cooking together among the positive posts. Photos of daily life were common among neutral shares. These photos seemed to be taken without a specific purpose, such as photos of a child on a swing. In terms of negative posts, the unpleasant times due to COVID-19 were also posted. For instance, the common themes were related to the boredom, complaints, and criticisms about handling the pandemic and the monotonous way of living due to quarantine. Nevertheless, the parents' posts on social media during the quarantine period were largely optimistic.

\section{Content of the Posts}

The posts were also handled in terms of their content and were categorised as such. These categories were determined according to the topics of the parents' posts. The posts analysed for \#korona (\#corona) included ones addressing a learning activity $(\mathrm{n}=51)$ with playing and art, cooking together and playing sports at home. As well as that, posts with criticisms and complaints about the pandemic $(n=25)$ and posts under the heading of 'miscellaneous' $(\mathrm{n}=150)$ were also included. These include posts specifically about April 23 - National Sovereignty and Children's Day. Regarding the content of the posts for \#evdekal (\#stayhome), most of them were 'activities' (n=97), including learning plays, Montessori activities, cooking with children, etc. The category 'miscellaneous' $(n=78)$ was mainly about 'stay at home' messages, anniversaries (e.g., the child's birthday), commercials, TikTok videos recorded in the household, such as ones expressing boredom in a funny way. Only one critical post was found, warning parents not to force their children to do anything that the children do not want to do.

Since the data collection period also covered April 23, National Sovereignty and Children's Day, a national holiday in Turkey, a considerable amount of content in the current category consisted of children reading poems, singing April 23 songs or marches and drawing pictures related to the day $(\mathrm{n}=64)$. On this day, taking photos with children while doing various activities was quite common, and in those posts, the focus was the child themselves. More specifically, prior to the pandemic, April 23 had been celebrated in schools and at stadiums within huge ceremonies. However, these celebrations were primarily held on social media, as a form of sharenting, due to the pandemic and quarantine in 2020.

Within the 'miscellaneous' category, most of the posts were about the daily lives of families. To be more precise, the posts consist of going on vacation with children, celebrating birthdays and anniversaries, TikTok videos, getting haircuts together, and widespread challenges across social media (Montag, Yang, \& Elhai, 2021). For instance, there are water challenges on social media which serve as an example of how social media is integrated into family life. 
Figure 3.

Hashtags Accompanying \#korona (\#corona)

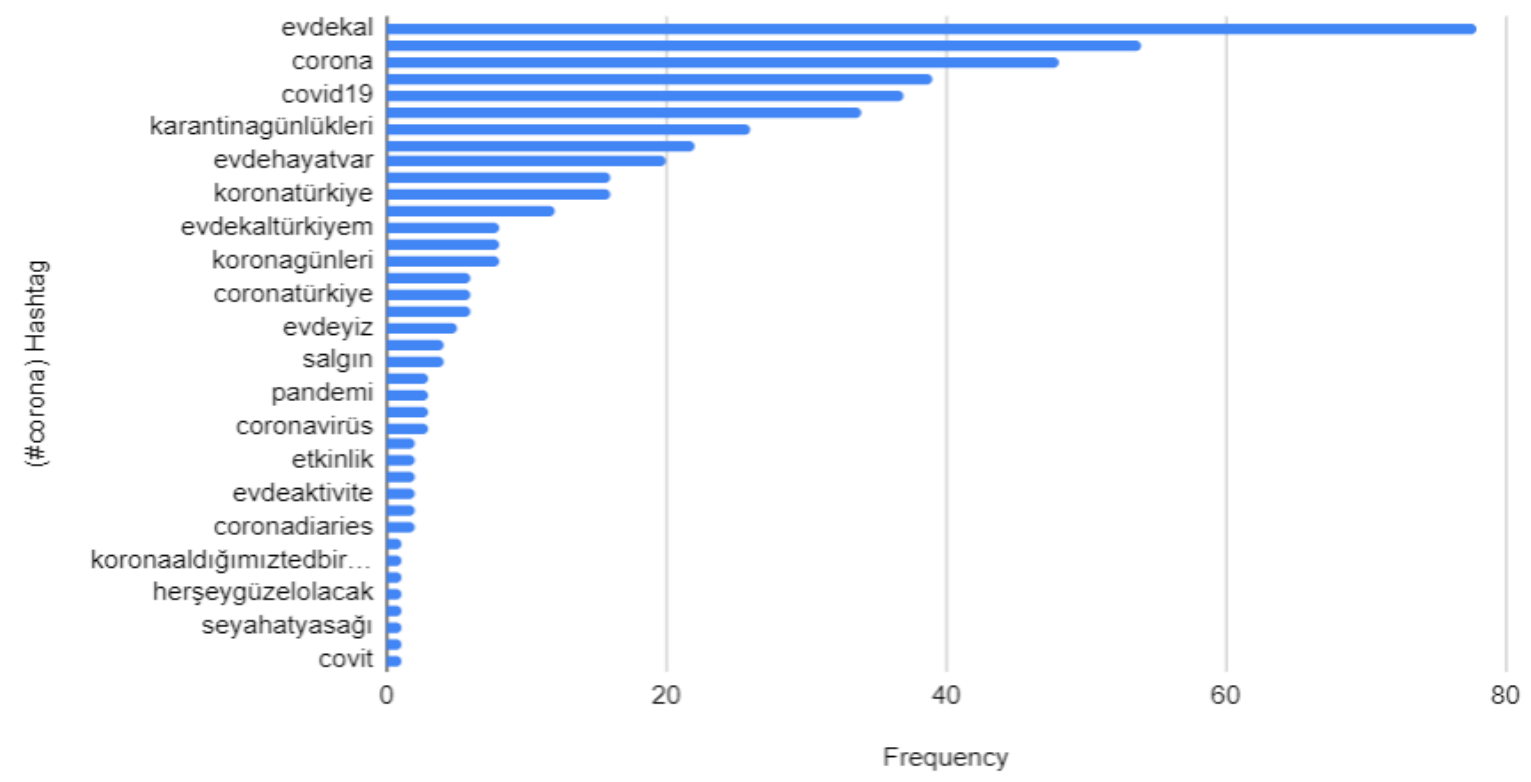

In terms of accompanying hashtags related to \#korona (\#corona), 65 different hashtags were observed and presented in Figure 3. The most frequent ones which were used together were \#evdekal (\#stayhome), $(\mathrm{n}=78)$, \#evdekaltürkiye $(\mathrm{n}=54)$, \#corona $(\mathrm{n}=48)$, \#quarantine $(\mathrm{n}=39)$, \#covid19 $(\mathrm{n}=37)$, \#lifefitsintohome $(n=34)$, \#quarantinediaries $(n=26)$, \#koronavirus $(n=22)$, \#lifeathome $(n=20)$, and \#koronatürkiye $(\mathrm{n}=16)$. The other hashtags with low frequency revealed the importance of spending time with family and health issues related to COVID-19. Accordingly, accompanying hashtags, including the virus itself and its worldwide effects like staying at home and being locked down, were shared mostly on social media platforms.

\section{Figure 4.}

Hashtags Accompanying \#evdekal (\#stayhome)

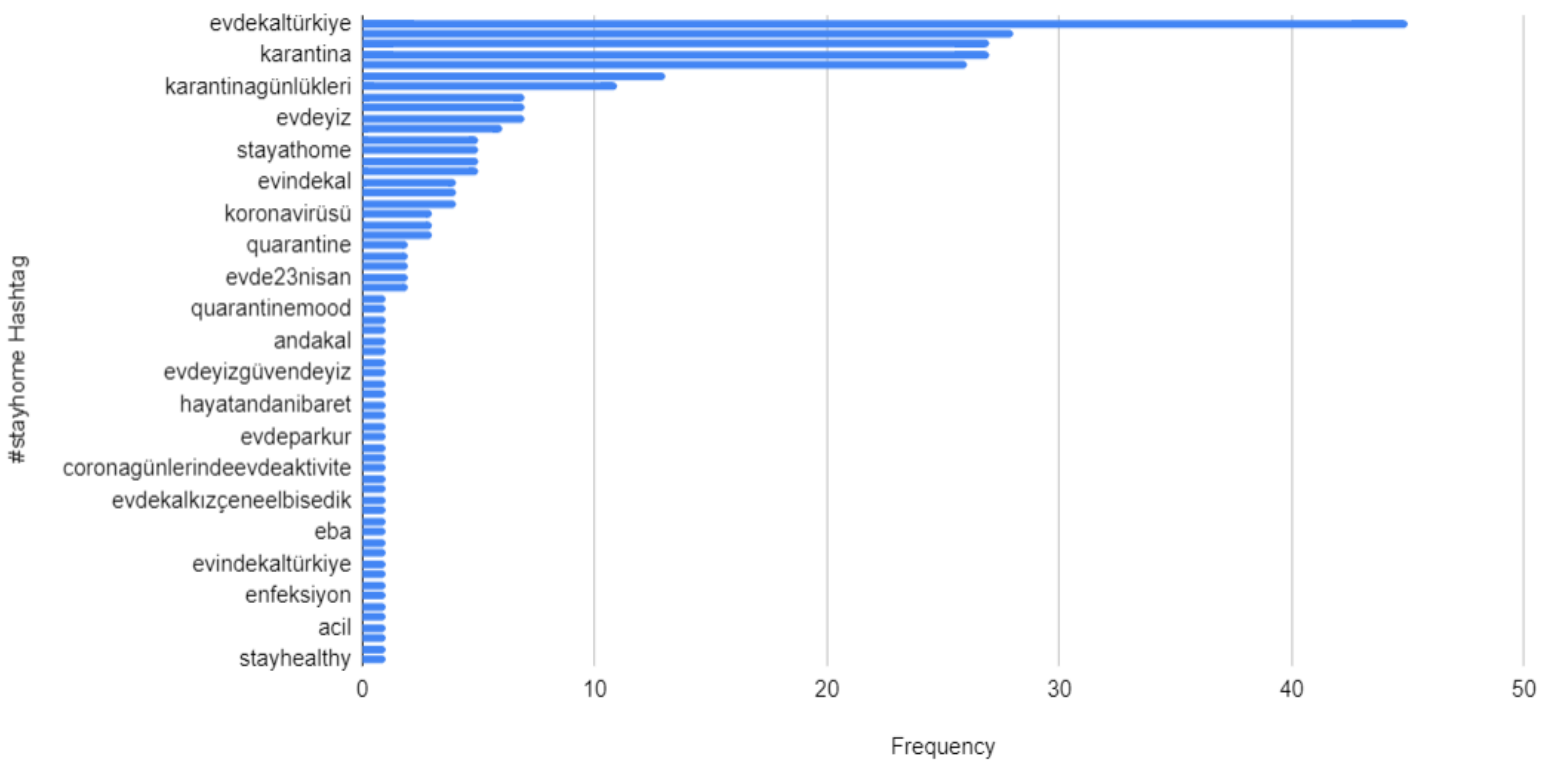

Regarding accompanying hashtags related to \#evdekal (\#stayhome), a total of 61 distinct hashtags were identified and are presented in Figure 4. The most common one was \#evdekaltürkiye $(n=45)$, followed by \#korona ( $\mathrm{n}=28)$, \#hayatevesı ğar $(\mathrm{n}=27)$, \#quarantine $(\mathrm{n}=27)$, and \#stayhome $(\mathrm{n}=26)$. In line with the 
positive association of \#evdekal (\#stayhome), these findings also seem to be emphasising the positive attitudes towards COVID-19 lockdowns and sharenting on Instagram. \#evdekal (\#stayhome) might be promising in terms of its positive and hopeful connotation on individuals' responsibility and sensitivity towards others in society. In that regard, given that the hashtags are in tune with Adler's social interest, an interest in the interest of others, behaviours and attitudes that display a sense of fellowship, responsibility, and community with others are key for both physical and psychological functioning (Adler, 2019). Besides, the integration of "Türkiye" (Turkey) in the given hashtags might also be a sign of social unity during the pandemic.

\section{DISCUSSION AND CONCLUSION}

Sharenting on Instagram during the quarantine period highlights how the issue has become more critical. Trends and changes in social media usage, which have significantly increased both over holidays and during usually less busy times, have been reported (MacKay et al., 2017). Parents probably used social media more than before during the early days of the COVID-19 pandemic, including the early lockdowns. One possible explanation for this change might be that parents had more time to share with their children. Commonly used social media platforms such as Instagram may offer an opportunity to alleviate social isolation (Primack et al., 2017). This period made people live more closely with their family members, so investigating parents' shares during this particular time is very important.

Similarly, during the COVID-19 period, so as not to lose social connections, parents probably engaged in more shares on social media. This can also be explained by social motivation (Ryan, \& Deci, 2000) by seeking more social support from online platforms, enabling parents to share their own parenting experiences by posting comments or sharing information about their children (Kumar, \& Schoenebeck, 2015). Sharenting during these times probably helped parents highlight that they are active and they have something to share.

The findings of this research showed a considerable number of parental shares about their children. Undoubtedly, the shares reached through this study were only a small part of all parental shares on social media. Nevertheless, even this limited investigation pointed to the widespread existence of parental shares about their children. Results show that mothers rather than fathers engaged in sharenting during this period. The majority of the literature points out that sharenting on social media is dominantly done by mothers (Davis et al., 2015). Similarly, a sharenting study in Turkey revealed that $77.73 \%$ of participants were mothers (Maraşl1 et al., 2016). Brosch (2016) stated that parents are happy and excited to display their children's development and learning process, which possibly applies to mothers more than fathers. There is research on mothers spending their days with a newborn baby at home (Archer, \& Kao, 2018; Duggan et al., 2015; Latipath et al., 2020). Mothers are sharenting to keep in touch with relatives and friends as they do not want to be deprived of a social life. It is interesting to note that when grandmothers share posts about their grandchildren, mothers are often concerned about the effects that this will have on the child's digital footprint (Cino, \& Dalledonne-Vandini, 2020). Another reason for using social media is that mothers gain psychological satisfaction. Mothers are sharenting because they want to show how good and competent their children are (De Wolf, 2020; Gibson \& Hanson, 2013; Maraşl1 et al., 2016; Ouwrein \& Versvijvel, 2019) and are motivated by the likes they get from others. Similar to the given findings, the results of the current study presented that posts are shared mainly by mothers who have even been termed as 'insta-moms' (Altun, 2019; Choi \& Lewallen, 2018). A crosscultural study also identified that regardless of culture, mothers tend to share their children's photos and/or videos on social media, especially to show their pride and gain psychological satisfaction (Günüç, 2020).

When the above research about sharenting is compared to the current study's findings, it is not hard to see that most shares are of very young children. The number of posts of children between the ages of 0 and 2 and preschool children was higher than school-age children. This shows that most posts include 
children from birth to school age, which is consistent with the research result (Altun, 2019). For centuries, parents have collected memories of their children by keeping diaries and photo albums (Kumar et al., 2019). Today parents share photos, special times, and even private moments with their children on social media. The reason might be that parents do not want to miss special moments in their children's lives while they are growing up. They share each moment on digital platforms without getting permission from their children. On the other hand, while they tell stories about their children's private life, they miss the danger of leaving their children's digital footprint (Steinberg, 2017).

Another finding is that children's faces are mostly visible (not blurred out or covered) in the posts investigated. This might be an essential concern for the privacy of children. Parents are violating the privacy rights and information security of their children. According to the United Nations Children's Rights Convention (1989), all people under the age of 18 are considered children, and their protection from abuse, risk, and deprivation is a fundamental right. However, this is infringed by parents who are sharenting (Lynch, \& Liefaard, 2020). Article 12 claims that States shall assure that children have the right to express their views freely in all matters affecting them, the views of the child being given due weight according to the age and maturity of the child. Article 16 says that no child shall be subjected to arbitrary or unlawful interference with their privacy, family, home or correspondence, nor to criminal attacks on their honour and reputation. Article 19 says that States shall take all appropriate legislative, administrative, social and educational measures to protect the child from all forms of physical or mental violence, injury or abuse, neglect or negligent treatment, maltreatment or exploitation, including sexual abuse, while in the care of parent(s), legal guardian(s) or any other person who has the care of the child. When these articles are examined, it is evident that whenever parents share their children's photos or videos without blurring their faces on social media, they expose their children without their permission and violate their privacy. Although the parents are seen as the primary protector of their children, they display irresponsible behaviour by using social media and sharing their children's videos and photos (Archer, \& Kao, 2018; Bessant, 2018; Moser et al., 2017).

For instance, in one post, even though the preschool son did not want his mother to take a video of him, she continued recording the child during dinner. Similarly, another mother's video records her infant son without his knowledge, as he was focused on watching television. These examples should be considered ethical issues and seem questionable in terms of the quality of the communication among family members. Moreover, these shares are subject to be insulted and made fun of, leading to psychological abuse of the child in the future. According to the European Human Rights Convention (1950), the 8th article states that everyone has the right to respect in their private and family life, home, and correspondence. This article, therefore, explicitly restricts the displaying of photos and videos of children.

There has been an ongoing indication in the literature that parents' disclosures online might cause harm to their children, intentionally or not (Steinberg, 2017), which was apparent in the findings of this research. Parents share images of children without blurring their faces and also include personal information about the child, which may result in digital kidnapping (Cino, \& Dalledonne-Vandini, 2020). Parents think that only their followers see the posts, and the parents would never consider sharing the photos or videos with others. The photos or videos may rapidly end up in the hands of ill-intentioned individuals (Brosch, 2019). Identifying the child's face, where the child lives, the address of the school they go to, publishing the child's image, sharing their birthday, or showing what they like or dislike creates a potential digital abduction environment for children, creating a real potential danger. A stranger can steal a child's images from social media and use this child's identity or image. The stranger may use the information provided and pretend that the child is their own. Therefore, parental education about such matters might be necessary for implications regarding further studies (Blum-Ross, \& Livingstone, 2017). This research did not aim to find the connection between the content of the posts and the consequences, however, this could be considered for further research.

In tune with the nature of social media, our findings pointed that positive messages are frequently observed in the posts in terms of positive facial expressions, body language such as hugging, and 
emoticons such as hearts, smiling faces and so forth. Concerning the content of the posts, daily life photos dominate the content. For example, celebrating the birthdays and anniversaries of children, TikTok videos, getting haircuts together and taking part in viral social media challenges such as water challenges. Even though the timeframe was short, the variety of interactive activities could be linked to families spending more time together due to quarantine. Even though the pandemic might be considered a vulnerable period of adverse psychological and physiological outcomes, most of the posts on social media included positive content for both hashtags (Kross et al., 2013). Research done in the area showed consistent results with the current research. Parents frequently share happy moments (Brosch, 2016; Maraşlı et al., 2016), such as special days, celebrations, and activities. This situation might be considered a coping strategy adopted by parents to hinder the pandemic's adverse psychological and physiological effects. On the other hand, parents made posts during the pandemic to receive likes and satisfy their parental pride (Lazard et al., 2019). Findings also show that accompanying hashtags used by parents also reflected the COVID-19 period, mostly with themes of the home, staying at home, and health and safety. The posts were mostly positive in nature, which is also typical of social media shares (Bekalu, McCloud, \& Viswanath, 2019).

There are some limitations of this research, with some already explained above, and those could be considered for future studies on sharenting. This study is limited only to the shared photos and videos recorded based on two determining hashtags. Captions related to the posts written by users were not included in the research. Moreover, the number of likes and comments on these posts were not investigated. Live streams and stories were also left out of the scope. Only posts made within a select timeframe were examined following certain variables such as the frequency of the posts, the content, or the direction of the shares. Only one social media platform (Instagram) was used to collect data. For future studies, resolutions for these issues could be recommended to the researchers, leading to further studies on sharenting. Lastly, the developmental stage of children may be investigated in detail, such as focusing only on shares of babies, etc. In addition to facial expressions, the body language of children can also be investigated for representations of children on social media.

Sharenting is also a need for self-realisation and social approval in the literature (Brosch, 2016). Therefore, sharenting could also be investigated from a psychological point of view. Even though the content of posts made during the quarantine period was the aim of this investigation, results showed that using popular hashtags within a given period might enhance the accessibility and popularity of posts. Adler emphasised that the 'need for belonging' is fundamental for healthy psychological functioning in the social community (Sweeney, 2009). For that reason, children might be a mediator to satisfy parents' needs of belonging. by satisfying their needs in such a way, privacy and ethical considerations are not taken into account and seem to require further investigation.

Although studies in Turkey are limited, this study might be promising as the first sharenting study conducted in the COVID-19 period. More precisely, we found that parents mostly share their activities while spending time with their families. Sharenting seems to be a common parental behaviour among today's parents and should be explored in different times and periods, with other social media platforms, and including more in-depth information about the shares (Zafri et al., 2021). However, all in all, the awareness of parents about the impact and potential consequences are crucial in terms of public health, psychological well-being and the safety of children.

\section{REFERENCES}

Adler, A. (1927). Understanding Human Nature. [Menschenkenntnis]. Greenberg.

Akee, R., Copeland, W., Costello, E. J., \& Simeonova, E. (2018). How does household income affect child personality traits and behaviors? American Economic Review, 108 (3), 775-827. https://doi.org/10.3386/w21562

Altun, D. (2019). An investigation of preschool children's digital footprints and screen times, and of parents' sharenting and digital parenting roles. International Journal of Eurasia Social Sciences, 10(35), 76-97. 
Archer, C., \& Kao, K.T. (2018). Mother, baby and Facebook makes three: does social media provide social support for new mothers? Media International Australia, 168(1), 122-139. https://doi.org/10.1177/1329878X18783016

Atl1, S., Gunuc, S. , Kuss, D. \& Baran, G. (2019). Impact of parents' technology use on 18- to 24-month-old infants' adaptive behaviors. Adaptive Behavior, 27(3) 197-219. https://doi.org/10.1177/1059712319845340

Bekalu, M. A., McCloud, R. F., \& Viswanath, K. (2019). Association of social media use with social well-being, positive mental health, and self-rated health: Disentangling routine use from emotional connection to use. Health Education \& Behavior, 46(2), 69-80. https://doi.org/10.1177/1090198119863768

Bessant, C. (2018). Sharenting: Balancing conflicting rights of parents and children. Journal of Computer, Media and Telecommunication Law, 23(1), 1-3.

Blum-Ross, A. \& Livingstone, S. (2017). Sharenting, parent blogging, and the boundaries of the digital self. Popular Communication, 15(2), 110-125. https://doi.org/10.1080/15405702.2016.1223300

Hewson, C. \&Buchanan, T. (2013). Ethics Guidelines for Internet-mediated Research. The British Psychological Society.

Bronfenbrenner, U. (2005). Ecological systems theory. Sage Publications.

Brosch, A. (2016). When the child is born into the internet: Sharenting as a growing trend among parents on Facebook. The New Educational Review, 43(1), 225-235. https://doi.org/10.15804/tner.2016.43.1.19

Choi, G. Y., \& Lewallen, J. (2018). "Say Instagram, Kids!": Examining Sharenting and Children's Digital Representations on Instagram. Howard Journal of Communications, 29(2), 140-160. https://doi.org/10.1080/10646175.2017.1327380

Cino, D., \& Dalledonne Vandini, C. (2020). "My kid, my rule": Governing children's digital footprints as a source of dialectical tensions between mothers and daughters-in-law. Studies in Communication Sciences, 20(2), 1-22. https://doi.org/10.24434/j.scoms.2020.02.003

Cohen, J. (1960). A coefficient of agreement for nominal scales. Educational Psychology and Measurement, 20, 37-46. https://doi.org/10.1177/001316446002000104

De Wolf, R. (2020). Contextualizing how teens manage personal and interpersonal privacy on social media. New media \& society, 22(6) 1058-1075. https://doi.org/10.1177/1461444819876570

Davidson-Wall, N. (2018, April). “Mum, seriously!” Sharenting the new social trend with no opt out [Paper presentation]. The $9^{\text {th }}$ Debating Communities and Social Networks OUA Conference. http://networkconference.netstudies.org/2018OUA/2018/04/22/mum-seriously-sharenting-the-new-socialtrend-with-no-opt-out/

Davis, M., Clark, S. J., Singer, D. C., Hale, K., Matos-Moreno, A., \& Kauffman, A. D. (2015). Parents on social media: Likes and dislikes of sharenting, C.S. Mott Children's Hospital National Poll on Children's Health. 23(2), 1-2.

Demir, T., \& Drentea, P. (2016). Family as a social institution. In C.L. Shehan (Ed.), Encyclopedia of Family Studies. Wiley Online Library.

Drouin, M., McDaniel, B. T., Pater, J., \& Toscos, T. (2020). How parents and their children used social media and technology at the beginning of the COVID-19 pandemic and associations with anxiety. Cyberpsychology, Behavior, and Social Networking, 23(11), 727-736. https://doi.org/10.1089/cyber.2020.0284

Duggan, M., Lenhart, A., Lampe, C., \& Ellison, N. (2015). Parents and social media: Mothers are especially likely to give and receive support on social media. Pew Research Center.

Erişir, M. R., \& Erişir, D. (2018). Children and the new media: Example of "sharenting" specified to Instagram. New Media, (4)5, 50-63.

Gibson, L., \& Hanson, V. L. (2013). Digital motherhood: How does technology help new mothers? Human Factors in Computing Systems, 313-322, https://dl.acm.org/doi/10.1145/2470654.2470700.

Günüç, S. (2020). Examining 'sharenting' from a psychological perspective: Comparing Turkish and British mothers. Current Approaches in Psychiatry, 12, 281-297. https://doi.org/10.18863/pgy.795651

Gwet, K.L. (2014). Handbook of Inter-Rater Reliability: The Definitive Guide to Measuring the Extent of Agreement Among Raters. Advanced Analytics, LLC.

Imran, N., Zeshan, M., \& Pervaiz, Z. (2020). Mental health considerations for children \& adolescents in COVID19 Pandemic. Pakistan Journal of Medical Sciences, 36, 1-6. https://doi.org/10.12669/pjms.36.COVID19S4.2759

Kross E., Verduyn P., Demiralp E., Park J., Lee D.S., Lin, N., Shablack, H., Jonides, J., \& Ybarra, O. (2013). Facebook use predicts declines in subjective wellbeing in young adults. Plos One, 8(8), e69841. https://doi.org/10.1371/journal.pone.0069841

Kumar, P., \& Schoenebeck, S. (2015). The modern day baby book: Enacting good mothering and stewarding privacy on Facebook. In Proceedings of the $18^{\text {th }}$ ACM Conference on Computer Supported Cooperative Work \& Social Computing, ACM, 1302-1312. https://doi.org/10.1145/2675133.2675149 
Lacsa, J. E. (2021). \#COVID19: Hashtags and the power of social media. Journal of Public Health, fdap242, 1-2. https://doi.org/10.1093/pubmed/fdab242

Latipah, E., Kistoro H. C. A, Hasanah, F.F., \& Putranta, H. (2020). Elaborating motive and psychological impact of sharenting in millennial parents. Universal Journal of Educational Research, 8(10), 4807-4817. https://doi: 10.13189/ujer.2020.081052

Lazard, L., Capdevila, R., Dann, C., Locke, A., \& Roper, S. (2019). Sharenting: Pride, affect and day to day politics of digital mothering. Social Personal Psychological Compass. 13, e12443. https://doi.org/10.1111/spc3.12443

Lynch, N., \& Liefaard, T. (2020). What is left in the "too hard basket"? Developments and challenges for the rights of children in conflict with the law. International Journal of Children's Rights, 28, 89-110. https://doi.org/10.1163/15718182-02801007

MacKay, K., Barbe, D., Van Winkle, C.M. \& Halpenny, E. (2017). Social media activity in a festival context: temporal and content analysis. International Journal of Contemporary Hospitality Management, 29(2), 669-689. https://doi.org/10.1108/IJCHM-10-2015-0618

Maraşl1, M., Sühendan, E., Yılmaztürk, N. H., \& Çok, F. (2016). Parents' shares on social networking sites about their children: Sharenting, Anthropologist, 24 (2), 399-406.

Montag, C., Yang, H., \& Elhai, J. D. (2021). On the psychology of TikTok use: A first glimpse from empirical findings. Frontiers in Public Health, 9, 1-6. https://doi.org/10.3389/fpubh.2021.641673

Moser, C., Chen T., \& Schoenebeck, S.Y. (2017). Parents' and children's preferences about parents sharing about children on social media. Human Factors in Computing Systems, 5221-5225. https://doi.org/10.1145/3025453.3025587

Naidui, S. (2021). Reimagining education futures to lead learning for tomorrow. Distance Education, 42:3, 327 330. https://doi.org/10.1080/01587919.2021.1956306

Nesmith,A., Patton,R., Christophersen K., \& Smart, C. (2017). Promoting quality parent-child visits: the power of the parent-foster parent relationship. Child and Family Social Work, 22, 246-255. https://doi.org/10.1111/cfs.12230

Niknam, F., Samadbeik, M., Fatehi, F., Shirdel, M., Rezazadeh, M., \& Bastani, P. (2021). COVID-19 on Instagram: A content analysis of selected accounts. Health Policy and Technology, 10(1), 165-173. https://doi.org/10.1016/j.hlpt.2020.10.016

Ouwrein, G., \& Versvijvel, K. (2019). Sharenting: Parental adoration or public humiliation? A focus group study on adolescents' experiences with sharenting against the background of their own impression management. Children and Youth Services Review, 99, 319-327. https://doi.org/10.1016/j.childyouth.2019.02.011

Özer, M. (2020). Educational policy actions by the ministry of national education in the times of COVID-19. Kastamonu Education Journal, 28(3), 1124-1129. https://doi.org/1 10.24106/kefdergi.722280

Patton, M. Q. (2015). Qualitative evaluation and research methods. Sage.

Primack, B. A., Shensa, A., Sidani, J. E., Whaite, E. O., Lin, L. yi, Rosen, D., Colditz, J. B., Radovic, A., \& Miller, E. (2017). Social media use and perceived social isolation among young adults in the U.S. American Journal of Preventive Medicine, 53(1), 1-8. https://doi.org 10.1016/j.amepre.2017.01.010

Ryan, R. M., \& Deci, E. L. (2000). Intrinsic and extrinsic motivations: Classic definitions and new directions. Contemporary Educational Psychology, 25, 54-67. https://doi.org/10.1006/ceps.1999.1020

Sprang, G., \& Silman, M. (2013). Posttraumatic stress disorder in parents and youth after health-related disasters. Disaster Medicine and Public Health Preparedness, 7(1), 105-110. https://doi.org/10.1017/dmp.2013.22

Steinberg, S. B. (2017). Sharenting: Children's privacy in the age of social media. Emory Law Journal, 66, 839884.

Sweeney, T. J. (2009). Adlerian counseling and psychotherapy: A practitioner's approach. Routledge.

Timmons, K., Cooper, A., Bozek, E. Braund, H. (2021). The impacts of COVID-19 on early childhood education: Capturing the unique challenges associated with remote teaching and learning in K-2. Early Childhood Education Journal, 49, 887-901. https://doi.org/10.1007/s10643-021-01207-z

Ural, O., \& Ramazan, O. (2007). From past to today early childhood education in Turkey. In proceedings of the $3^{\text {rd }}$ TED New Horizons in Education Symposium on Problems of Early Childhood Education and Elementary School, 13-17. https://doi.org/10.17569/tojqi.308590

Williams, K. (2009). Mother's pride: Parenting against the grain. Gender and Education,21(4), 467-470. https://doi.org/10.1080/09540250903011350

Zafri, N. M., Afroj, S., Nafi, I. M., \& Hasan, M. M. (2021). A content analysis of newspaper coverage of COVID19 pandemic for developing a pandemic management framework. Heliyon, 7(3), e06544. https://doi.org/10.1016/j.heliyon.2021.e06544 


\section{TÜRKÇE GENIŞLETILMIŞ ÖZET}

Günümüzde, COVID-19 nedeniyle zor günler geçirmektedir. Birleşmiş Milletler Eğitim, Bilim ve Kültür Örgütü’nün raporuna göre sosyal izolasyon, sokağa çıkma yasağı ve sosyal mesafe gibi kavramları beraberinde getiren pandemi nedeniyle, Mayıs 2020 itibariyle, 185 'i aşkın ülkede 1.5 milyar öğrenci örgün eğitime devlet kararı ile ara vermiş ve/veya uzaktan sürdürmek durumunda kalmıştır (Timmons vd., 2021). Türkiye'de 16 Mart 2020 itibariyle okullar kapanmış, 18 milyon 108 bin 860 öğrenci evlerinde, uzaktan eğitim sürecine geçmiştir. Çocuklar ve gençler kendilerini yalnız, endişeli, sıkılmıș ve kararsız hissedebildikleri gibi aynı șekilde, yetișkinler de sınırlamalar ve benzer duygular yaşamalarından dolayı dijital dünyaya daha çok sarılmışlar, belirsizlikle yaşama duygularıyla başa çıkmalarına dijital dünyadan yardım aramışlardır (İmran vd., 2020). Çocukların ve pek çok anababanın evde kaaplı oldukları bu süreçte Anababaların, çocuklarıyla birlikte gün boyu yaptıklarını gösterebilecekleri sosyal medya platformları kolayca ulaşılabilen araçlar olmuştur.

Anababaların sosyal medyada çocuklarını paylaşımları (sharenting) görece yeni olan ve anababaların çocuklarıyla ilgili sosyal medya paylaşımlarına atıfta bulunan bir kavramdır (Brosch, 2016). Anababaların bu tür paylaşımlarının arka planında sosyal onaylanma ve kendini gerçekleştirme gibi ihtiyaçlarını karşılama güdüleri olabilmektedir. Ancak bu tür paylaşımlar, dijital çocuk kaçırma, çocuğun fotoğraflarını çalarak sahte sosyal kimlik oluşturma gibi öngörülemeyen ve dikkat edilmesi gereken sonuçları beraberinde getirebilmektedir (Davidson-Wall, 2018).

Piaget, Vygotsky, Kohlberg, Erikson, Freud ve Adler gibi çocuk gelişimi üzerine önemli katkı sağlayan birçok kuramcı kaliteli anababa-çocuk etkileşimine vurgu yapmaktadır. (Ural ve Ramazan, 2007; Sweeney, 2009; Nesmith vd., 2017). Anababa ve çocuk arasındaki etkileşimin çocuğun her anlamda gelişimi açısından da önemli olduğu bilinmektedir (Bronfenbrenner, 2005; Sweeney, 2009). Bu bağlamda anababanın iyi oluşu, duygu durumu ve kişilik özelliklerinin çocuğun kişilik ve davranışı üzerinde etkilidir (Akee vd., 2018; Davis vd., 2015).

Günümüzde sosyal medya, anababaların kabul gördükleri bir platform olarak kabul edilmekte ve çocuklarıyla yaptıkları etkinlikleri sergileyerek ebeveynlik becerilerini tatmin etme firsatı bulmaktadırlar (Brosch, 2016; Lazard vd., 2019). Bu amaçla, çocuklarının çok sayıda fotoğrafını veya videosunu paylaşıp ve muhtemelen kendilerini daha iyi hissetmelerini sağlayacak beğeniler ve tepkiler beklemektedirler. $\mathrm{Bu}$ çalışma Türkiye'de COVID-19 ve karantina zamanlarındaki anababa paylaşımlarının içeriğini araştırmayı amaçlamaktadır.

Pandeminin başlangıcı sayilabilecek 18-30 Nisan 2020 tarihleri arasında, popüler hashtagler olan \#korona ve \#evdekal incelenerek anababaların herkese açık Instagram paylaşımları üzerinden kendi çocuklarının fotoğraflarını/videolarını paylaştı̆̆ toplam 401 içeriğe ulaşılmıştır. Bunlardan 226 tanesi korona hashtagine aittir. Belirlenen kategoriler dahilinde içerik analizi gerçekleştirilmiştir. Paylaşımlardan yola çıkılarak belirlenen bu kategoriler; paylaşımın içeriği (fotoğraf/video), paylaşımı yapan kişi (anne/baba), paylaşılan çocuğun gelişim dönemi ( $0-2$ yaş, okul öncesi dönem, ilköğretim, lise, üniversite), çocuğun yüzünün görünürlüğü, paylaşımın içeriği (olumlu/nötr/olumsuz), paylaşımın içeriği (aktivite, eleştiri, günlük yaşam vb.), (varsa) eşlik eden hashtagler şeklindedir. Veriler, ekran alıntısı yoluyla gün bazında kaydedilmiştir. Değerlendiriciler arası güvenirlik katsayısı her iki hashtag için de kategoriler bazından \%75-\%100 arasında değişiklik göstermekte ve güvenilirdir (Cohen, 1960).

Anababaların çocuklarıyla ilgili paylaşımlarında korona hashtagi için günlük 17, evdekal hashtagi için günlük 13 paylaşımda bulundukları gözlenmiştir. Paylaşımların, bu yıl evlerde coşkuyla kutlanmak durumunda kalınan 23 Nisan tarihinde her iki hashtag için de pik yaptığı görülmüştür. Her iki hashtag için de anneler daha sık paylaşım yapmasının yanı sıra videodan ziyade fotoğraf paylaşımlarına daha çok yer verildiği görülmüştür. 
Çocukların gelişim dönemi göz önünde bulundurulduğunda en sık okul öncesi dönemdeki çocuklara ait paylaşımlarda bulunulurken en az üniversite dönemindekilerin paylaşıldığı saptanmıştır. Paylaşımların içerikleri incelendiğinde, 'diğer' kategorisinde yer alan günlük yaşama dair paylaşımların yanı sıra 23 Nisan'da şiir okuma, çocuğun yaptığı resme yer verme gibi içeriklere yer verilmiştir. Ayrıca, oyun oynama, birlikte bir şeyler pişirme ve yaratıcı etkinlik yapma da 'diğer' kategorisinden sonra sıkça yer verilen içeriklerdendir. Sosyal medya platformlarının doğasına uyumlu olarak sıklıkla olumlu paylaşımlara yer verilmiştir. Paylaşımlara eşlik eden hashtagler değerlendirildiğinde, söz konusu iki hastagten sonra görece popüler olan ve onlarla uyumlu 'karantina', 'covid', 'evdekaltürkiye' gibi hashtaglere sıkça yer verildiği gözlenmiştir.

Karantina ve pandemi döneminde sosyal medyanın kullanımındaki sıklık, anababaların çocuklarıyla ilgili paylaşımlarında da gözlenmiştir. Mekansal olarak daha sınırlı bir ortamda, evde aile fertleriyle bir arada olan anababalar yıl dönümleri, doğum günleri, 23 Nisan gibi ulusal bayramların yanı sıra çocuklarının günlük yaşamlarından da sıkça kareler paylaşmışlardır. Özellikle, önceki çalışmalarda 'Instagram anneleri' olarak da yer verilen annelerin sıkça sosyal medyada paylaşım yapması, karantina döneminde de devam etmiştir (Altun, 2019; Choi ve Lewallen, 2018).

S1k kullanılan \#evdekal etiketinin (\#stayathome) toplumda başkalarına karşı duyarlılık ve iyimser çağrışım yapması açısından umut verici olduğu söylenebilir. İçerik analizi çalışması, sosyal medyanın aile hayatına entegre olduğunu ve keyifli iş birliği için umut verici olabileceğini göstermektedir.

Çocukların yüzleri anababaları tarafından sosyal medyada gerçekleştirilen paylaşımlarda çoğunlukla erişebilirdir. Paylaşımların ağırlıklı olarak okul öncesi dönemdeki çocukların anababaları tarafından yapıldığı da göz önünde bulundurulduğunda, bu durum çocukların mahremiyetine ilişkin bir endişe yaratabilir. Bu nedenle, ebeveynlerin bu tür kavramlar hakkında farkındalık kazanmasını sağlayan eğitimler daha sonraki çalışmalar kapsamındaki önemli uygulamalara kaynaklık edebilir (Blum-Ross ve Livingstone, 2017). 